\title{
Path Coefficient Analysis in First Clonal Stage of Sugarcane (Saccharum officinarum L.)
}

\author{
G. Somu ${ }^{1 *}$, M.S.P. Kanavi ${ }^{3}$, C. Shashikumar ${ }^{2}$, Shivaray Navi $^{2}$ and N. Meena ${ }^{1}$ \\ ${ }^{1}$ AICRP on Sorghum, KVK, Chamarajanagar, India \\ ${ }^{2}$ AICRP on Cotton, KVK, Chamarajanagar, India \\ ${ }^{3}$ Dept. of Genetics and Plant Breeding, CoA, Hassan \\ University of Agricultural Sciences, Bengaluru, India \\ *Corresponding author
}

\begin{abstract}
A B S T R A C T
Statistical correlation coefficient is a measure that denotes the magnitude and direction of interrelationship between any two casually related variables. The information on the genotypic and phenotypic interrelationship of cane yield and sugar yield with their component characters interest would be of immense help to the sugarcane breeder. The character association will also help in the selection of superior genotypes from divergent population based on more than one interrelated characters. However, correlation coefficients, sometimes, may be misleading and thus, need to be partitioned into direct and indirect effects. It is important for a breeder to know how other characters influence a particular character before selecting the parental material for crossing purposes. Path coefficient analysis provides direct and indirect effects of component characters thereby enhancing the better understanding of true relationship of the component characters with yield.
\end{abstract}

Keywords

Genotypic,

Phenotypic,

Correlation

coefficient, Path

coefficient analysis

Article Info

Accepted:

18 August 2020

Available Online:

10 September 2020

\section{Introduction}

Sugarcane is a multipurpose crop that provides food, fodder, feed, fibre and fuel at an affordable price to the rural poor. Sugarcane has the unique and very useful characteristic of high sugar concentration accumulation. Hence, it is an important crop for sugar production. Its contribution to agricultural GDP is 10 per cent which is significant as the crop is grown by only 2.57 per cent of the gross cropped area in the country (Anon., 2017). 
Among the sugar crops, sugarcane, accounts for over 70 per cent of the world's sugar production (Anon., 2017). Sugarcane (Saccharum spp.) hybrids are a genetically complex crop of major economic importance in tropical and subtropical countries. Cane industry requires high sugar producing varieties with other desired agronomic traits.

Globally, sugarcane is cultivated over an area of $24.10 \mathrm{~m}$ ha with an annual production of 1329.3 million tonnes and an annual productivity of $75.70 \mathrm{t} / \mathrm{ha}$, In India, sugarcane is grown under diverse agroclimate situations covering an area of $5.2 \mathrm{~m}$ ha and production of 364.0 million tonnes of sugarcane with productivity of $70.39 \mathrm{t} / \mathrm{ha}$ (Anon., 2017). Principal sugarcane growing states are Karnataka, Tamilnadu, Maharashtra, Andhra Pradesh, Uttar Pradesh and Gujarat. In Karnataka sugarcane is grown in an area of 4.30 lakh hectare and production of 45.3 million tonnes of sugarcane with annual productivity of 93.80 t/ha (Anon., 2017). In Cauvery Command Area sugarcane is grown in an area of 0.61 lakh hectare with the production of 77.10 lakh tonnes of sugarcane and productivity of $101.80 \mathrm{t} / \mathrm{ha}$ (Anon., 2017). In India 24.39 million tonnes of sugar is produced, but the projected requirement of sugar by 2030 is 36 million tonnes which has to be achieved from the existing cane area through improved varieties and management for cane yield and sugar recovery as further expansion in area is not possible.

\section{Materials and Methods}

Fifty five genotypes selected from 2308 seedling nursery based on evaluation were planted in eksali, 2015. Each genotype was planted in two rows of $6.0 \mathrm{~m}$ length spaced at $90 \mathrm{~cm}$ apart $(2 \mathrm{R} \times 6 \mathrm{~m} \times 0.9 \mathrm{~m})$ with three budded setts per meter in augmented design with five blocks along with three checks viz.,
CoVC 99463, Co 86032 and Co 62175. All the recommended package of practices was adopted to raise the better crop stand.

\section{Data recorded in First Clonal Generation $\left(\mathrm{C}_{1}\right)$ crop}

Observations were recorded on the following traits for each genotype before and at the time of harvest in the settling nursery $\left(\mathrm{C}_{1}\right)$ crop.

1. Number of tillers/plot

2. Number of millable canes /plot

3. Millable cane length $(\mathrm{cm})$

4. Cane diameter $(\mathrm{cm})$

5. Number of internodes

6. Internode length $(\mathrm{cm})$

7. Single cane weight $(\mathrm{kg})$

8. Pol per cent juice

9. Brix per cent juice

10. CCS per cent

11. CCS cane yield

12. CCS yield (t/ha)

13. Purity per cent

14. Cane yield $(\mathrm{t} / \mathrm{ha})$

15. HRB Yield (t/ha)

\section{Results and Discussion}

\section{Path coefficient analysis}

The correlation values denote only the nature and extent of association existing between a pair of characters. A dependent character like yield is influenced by several component characters which are mutually associated. Each component has two path actions viz., direct effect on yield and indirect effects through components which are not revealed by correlation studies.

Path coefficient analysis measures the direct influence of one variable on another. Cane yield and its correlated characters were subjected to path analysis for partitioning the correlation values into direct and indirect 
effects through alternative path ways and the results are furnished in table 1 and Figure 1.

Direct and indirect effects of different component characters on cane yield in first clonal stage of sugarcane

\section{Direct effects of different component characters on cane yield}

Path analysis was carried out taking cane yield of 58 clones of sugarcane as dependent character and such of the characters having high correlation with cane yield viz., number of tillers, millable canes, cane length, cane diameter, number of internodes, internode length, single cane weight, CCS cane yield and CCS yield as independent variables (Table 1). The results revealed that, among the cane characters studied, HR Brix yield (t/ha) had highest positive direct effect of 1.3507 on cane yield followed by pol per cent (0.7161), single cane weight $(0.2798)$ and number of millable canes (0.0774). Number of internodes, cane diameter and inter node length exhibited lowest positive direct effects of $0.0049,0.0056$, and 0.0086 , respectively. While low direct contribution to cane yield by CCS cane yield (-0.2230), CCS yield ($0.4757)$ and number of tillers $(-0.0065)$ were found to be negative.

\section{Indirect effects of different component characters on cane yield}

\section{Number of tillers per plot}

Indirect contribution of this character on cane yield was positive through number of internodes while it had negative indirect effect for all remaining characters.

\section{Number of millable canes per plot}

Highest positive indirect effect of this character on cane yield was evident through number of tillers (0.0762) followed by HR Brix yield (0.0692), CCS yield (0.0686), cane diameter (0.0455), single cane weight (0.0344), CCS cane yield (0.0331), internode length (0.0099), Brix per cent (0.0071), millable cane length (0.0056), pol per cent (0.0053), CCS per cent (0.0046) and the study found that, number of inter nodes $(-0.0065)$ and purity per cent $(-0.0010)$ had negative contribution with less magnitude.

\section{Millable cane length}

This trait contributed positively to the cane yield through per cent $(0.0012)$, purity per cent (0.0003), pol per cent (0.0010) and CCS per cent (0.0010) while it contributed negatively via number of tillers $(-0.0003)$, number of millable cane $(-0.0005)$, cane diameter (-0.0004), number of internodes ($0.0023)$, inter node length (-0.0035), single cane weight $(-0.0042)$, CCS cane yield (0.0034), CCS yield (-0.0022) and HR Brix yield (-0.0023) which were low in magnitude.

\section{Cane diameter}

This character had positive indirect contribution on cane yield through CCS yield (0.0039) and HR Brix yield (0.0039) followed by CCS cane yield (0.0036), single cane weight (0.0035), number of millable cane (0.0033), number of tillers (0.0031), Brix per cent (0.0014), pol per cent (0.0011), CCS per cent (0.0010) and number of internode (0.0005) while it had negative indirect effect on cane yield via internode length (-0.0004).

\section{Number of internodes}

Highest positive indirect contribution of this character was seen through millable cane length (0.0016) followed by single cane weight (0.0015), CCS cane yield (0.0012), cane diameter (0.0004), HR Brix yield (0.0039) and CCS yield (0.0002 t/ha) while it 
had negative indirect effect through internode length (-0.0023), pol per cent (0.0009), CCS per cent (0.0009) and purity per cent (0.0009).

\section{Internode length}

It had positive direct effect on cane yield (0.0086) and positive indirect contribution was seen through other cane characters viz., millable cane length (0.0042) followed by single cane weight (0.0020), HR Brix yield (0.0018 ) and CCS yield (0.0018 t/ha), CCS cane yield (0.0014), number of millable canes (0.0012) and number of tillers (0.0011) was low. It influenced in negative direction on cane yield through number of internodes ($0.0041)$ and cane diameter (-0.0006), Brix per cent (-0.0004) and pol per cent (-0.0002).

\section{Single cane weight $(\mathrm{kg})$}

Indirect contribution of this character on cane yield was positive through CCS cane yield (0.2547), HR Brix yield (0.2171), CCS yield (0.2141), cane diameter $(0.1726)$, millable cane length (0.1613), number of millable canes (0.1244), number of tillers (0.1132), internode length (0.0649), number of internodes (0.0848), pol per cent (0.0004) and CCS per cent (0.0018). It had negative indirect contribution through Brix per cent (0.0017).

\section{Pol per cent juice}

Pol per cent juice had positive direct effect on cane yield (0.7161) and positive indirect effects via all the quality characters viz., CCS per cent (0.7121), Brix per cent juice (0.6737), purity per cent (0.5110), cane diameter (0.1436) and HR Brix yield (0.0995). While, it contributed negatively through number of internodes (-0.1283), millable cane length $(-0.1013)$ and internode length (-0.0139)

\section{Brix per cent juice}

Brix per cent juice had negative direct effect on cane yield ( $\mathrm{t} / \mathrm{ha}$ ), but it showed positive indirect effects on cane yield via millable cane length (0.0628), internode length (0.0184), number of internodes (0.0551) and single cane weight (0.0025).

\section{CCS per cent}

CCS per cent juice had negative direct effect on cane yield (-0.2818), but it showed positive influenced on cane yield indirectly through number of internodes (0.0519), millable cane length (0.0367) and internode length (0.0025).

\section{CCS cane yield}

This trait had negative direct effect on cane yield (-0.2230), It also exhibited negative indirect effect on cane yield through HR Brix yield (-0.1690), CCS yield (-0.1735) and cane diameter $(-0.1443)$.

\section{CCS yield (t/ha)}

This trait had negative direct effect on cane yield (-0.4757), It also exhibited negative indirect effect on cane yield through HR Brix yield (-0.4736), CCS cane yield (-0.3700), number of tillers (-0.4108), number of millable canes $(-0.4216)$ and cane diameter (0.3292).

\section{Purity per cent}

Purity per cent juice had negative direct effect on cane yield (-0.0697), but it showed positive indirect effects on cane yield via number of internodes (0.0127), millable cane length (0.0028) and number of millable canes (0.0009). 


\section{HR Brix yield (t/ha)}

The relationship between HR Brix yield and cane yield was positive and significant (0.991). This trait also exhibited the highest positive direct effect on cane yield (1.3507). HR Brix yield registered positive and high indirect effect on cane yield through CCS yield (1.3447), CCS cane yield (1.0236), single cane weight (1.0479), number of millable canes (1.2073) and number of tillers (1.1716). Residual effect was found to be very low (0.0396) which indicated that almost all the yield attributing characters were included.

Critical analysis of the results by path analysis revealed that the characters HR Brix yield, single cane weight, pol per cent and number of millable canes exhibited high positive direct effects on cane yield and many characters also exhibited their indirect positive effects on cane yield via these characters indicating that these are the major contributing characters to cane yield in sugarcane. Hence, direct selection for HR Brix yield, single cane weight and number of millable canes would be helpful for the improvement of cane yield in first clonal stage.

These three characters showed significant positive correlation among themselves and with number of tillers, internode number, internode length, millable cane length, cane diameter, CCS yield and CCS cane yield indicating that indirect selection based on these characters may be given importance in first clonal stage.

Similar results of positive direct effect on cane yield were also reported by several workers for number of millable canes (Charumathi, 2011) and Shanthi Priya (2013) ; for single cane weight (Charumathi, 2011 and Shanthi Priya, 2013) and for HR Brix yield (Ram et al., 2000). Direct effect of single cane weight on cane yield was also reported by Suresh Jaganur (2014) and Kasayya (2016). Direct effect of millable canes on cane yield was similar to the findings of Kang et al., (1989).

Brix per cent had negative direct effect on CCS yield (t/ha), but it was indirectly improve the CCS yield by all the quality characters such as pol per cent, CCS per cent, purity per cent, cane yield and CCS cane yield in positive way. Pol per cent had highest positive indirect effect on CCS yield per hectare through CCS per cent followed by purity per cent, cane yield and CCS cane yield. Guruprasad Hiremath (2012), Suresh Jaganur (2014) and Kasayya (2016), also observed pol per cent had positive indirect effect on CCS yield through CCS per cent only. Direct positive effect of CCS per cent on CCS yield ( $t / h a)$ was supplemented by positive indirect effects through pol per cent, purity per cent, cane yield and CCS cane yield. Thippeswamy et al., (2003) reported that CCS per cent had negative indirect effect on CCS yield ( $t / h a)$ via through Brix per cent, purity per cent but positive effect of pol per cent on cane yield. They also suggested that, breeder should be give importance to sucrose per cent rather than Brix per cent for improvement of quality.

In conclusion, path coefficient analysis observed that commercial cane sugar (CCS) yield ( $t / h a)$ had highest positive direct effect on cane yield followed by single cane weight, number of millable canes. Number of tillers, cane diameter, millable cane length and number of internodes showed low positive direct effect on cane yield. While other component characters such as internode length and CCS yield shows negative direct effect on cane yield. Number of millable canes had highest positive indirect effect on cane yield through CCS yield and number of tillers. 
Table.1 Direct (diagonal) and indirect effects of cane yield component traits on cane yield at phenotypic level in first clonal stage of sugarcane

\begin{tabular}{|c|c|c|c|c|c|c|c|c|c|c|c|c|c|c|}
\hline & $\mathbf{1}$ & $\mathbf{2}$ & $\mathbf{3}$ & $\mathbf{4}$ & $\mathbf{5}$ & $\mathbf{6}$ & $\mathbf{7}$ & $\mathbf{8}$ & $\mathbf{9}$ & $\mathbf{1 0}$ & $\mathbf{1 1}$ & $\mathbf{1 2}$ & $\mathbf{1 3}$ & $\mathbf{1 4}$ \\
\hline $\mathbf{1}$ & $\mathbf{- \mathbf { 0 . 0 0 6 5 }}$ & -0.0064 & -0.0003 & -0.0036 & 0.0006 & -0.0009 & -0.0026 & -0.0006 & -0.0007 & -0.0005 & -0.0026 & -0.0056 & -0.0001 & -0.0056 \\
\hline $\mathbf{2}$ & 0.0762 & $\mathbf{0 . 0 7 7 4}$ & 0.0056 & 0.0455 & -0.0065 & 0.0099 & 0.0344 & 0.0053 & 0.0071 & 0.0046 & 0.0331 & 0.0686 & -0.0010 & 0.0692 \\
\hline $\mathbf{3}$ & -0.0003 & -0.0005 & $\mathbf{- 0 . 0 0 7 3}$ & -0.0004 & -0.0023 & -0.0035 & -0.0042 & 0.0010 & 0.0012 & 0.0010 & -0.0034 & -0.0022 & 0.0003 & -0.0023 \\
\hline $\mathbf{4}$ & 0.0031 & 0.0033 & 0.0003 & $\mathbf{0 . 0 0 5 6}$ & 0.0005 & -0.0004 & 0.0035 & 0.0011 & 0.0014 & 0.0010 & 0.0036 & 0.0039 & 0.0001 & 0.0039 \\
\hline $\mathbf{5}$ & -0.0005 & -0.0004 & 0.0016 & 0.0004 & $\mathbf{0 . 0 0 4 9}$ & -0.0023 & 0.0015 & -0.0009 & -0.0007 & -0.0009 & 0.0012 & 0.0002 & -0.0009 & 0.0003 \\
\hline $\mathbf{6}$ & 0.0012 & 0.0011 & 0.0042 & -0.0006 & -0.0041 & $\mathbf{0 . 0 0 8 6}$ & 0.0020 & -0.0002 & -0.0004 & -0.0001 & 0.0014 & 0.0018 & 0.0004 & 0.0018 \\
\hline $\mathbf{7}$ & 0.1132 & 0.1244 & 0.1613 & 0.1726 & 0.0848 & 0.0649 & $\mathbf{0 . 2 7 9 8}$ & 0.0004 & -0.0017 & 0.0018 & 0.2547 & 0.2141 & 0.0044 & 0.2171 \\
\hline $\mathbf{8}$ & 0.0610 & 0.0495 & -0.1013 & 0.1436 & -0.1283 & -0.0139 & 0.0011 & $\mathbf{0 . 7 1 6 1}$ & 0.6737 & 0.7121 & 0.2850 & 0.1462 & 0.5110 & 0.0995 \\
\hline $\mathbf{9}$ & -0.0399 & -0.0365 & 0.0628 & -0.0982 & 0.0551 & 0.0184 & 0.0025 & -0.3718 & $-\mathbf{0 . 3 9 5 2}$ & -0.3559 & -0.1416 & -0.0779 & -0.1719 & -0.0605 \\
\hline $\mathbf{1 0}$ & -0.0219 & -0.0168 & 0.0367 & -0.0513 & 0.0519 & 0.0025 & -0.0018 & -0.2802 & -0.2537 & $\mathbf{- 0 . 2 8 1 8}$ & -0.1138 & -0.0571 & -0.2203 & -0.0372 \\
\hline $\mathbf{1 1}$ & -0.0889 & -0.0954 & -0.1036 & -0.1443 & -0.0530 & -0.0363 & -0.2030 & -0.0888 & -0.0799 & -0.0900 & $-\mathbf{- 0 . 2 2 3 0}$ & -0.1735 & -0.0705 & -0.1690 \\
\hline $\mathbf{1 2}$ & -0.4108 & -0.4216 & -0.1411 & -0.3292 & -0.0179 & -0.0975 & -0.3640 & -0.0971 & -0.0938 & -0.0963 & -0.3700 & $\mathbf{- 0 . 4 7 5 7}$ & -0.0628 & -0.4736 \\
\hline $\mathbf{1 3}$ & -0.0010 & 0.0009 & 0.0028 & -0.0008 & 0.0127 & -0.0035 & -0.0011 & -0.0497 & -0.0303 & -0.0545 & -0.0220 & -0.0092 & $\mathbf{- 0 . 0 6 9 7}$ & -0.0035 \\
\hline $\mathbf{1 4}$ & 1.1716 & 1.2073 & 0.4197 & 0.9436 & 0.0717 & 0.2867 & 1.0479 & 0.1877 & 0.2069 & 0.1785 & 1.0236 & 1.3447 & 0.0671 & $\mathbf{1 . 3 5 0 7}$ \\
\hline $\mathbf{1 5}$ & $0.856 * *$ & $0.886 * *$ & $0.341 * *$ & $0.683 * *$ & 0.070 & 0.233 & $0.796 * *$ & 0.023 & 0.034 & 0.019 & $0.726 * *$ & $0.978 * *$ & -0.014 & $0.991 * *$ \\
\hline
\end{tabular}

\section{RESIDUAL EFFECT $=\mathbf{0 . 0 3 9 6}$}

\begin{tabular}{|c|l|l|l|}
\hline 1. & Tiller number & 9. & Brix per cent \\
\hline 2. & NMC & 10. & CCS per cent \\
\hline 3. & Millable cane length $(\mathrm{cm})$ & 11. & CCS cane yield \\
\hline 4. & Cane diameter $(\mathrm{cm})$ & 12. & CCS yield $(\mathrm{t} / \mathrm{ha})$ \\
\hline $\mathbf{5 .}$ & Number of internodes & 13. & Purity per cent \\
\hline 6. & Internode length $(\mathrm{cm})$ & 14. & HRB Yield $(\mathrm{t} / \mathrm{ha})$ \\
\hline 7. & Single cane weight $(\mathrm{kg})$ & 15. & Cane yield $(\mathrm{t} / \mathrm{ha})$ " $\mathrm{r}$ " value \\
\hline 8. & Pol per cent & & \\
\hline
\end{tabular}


Figure.1 Path diagram for cane yield at phenotypical level in first clonal stage of sugarcane

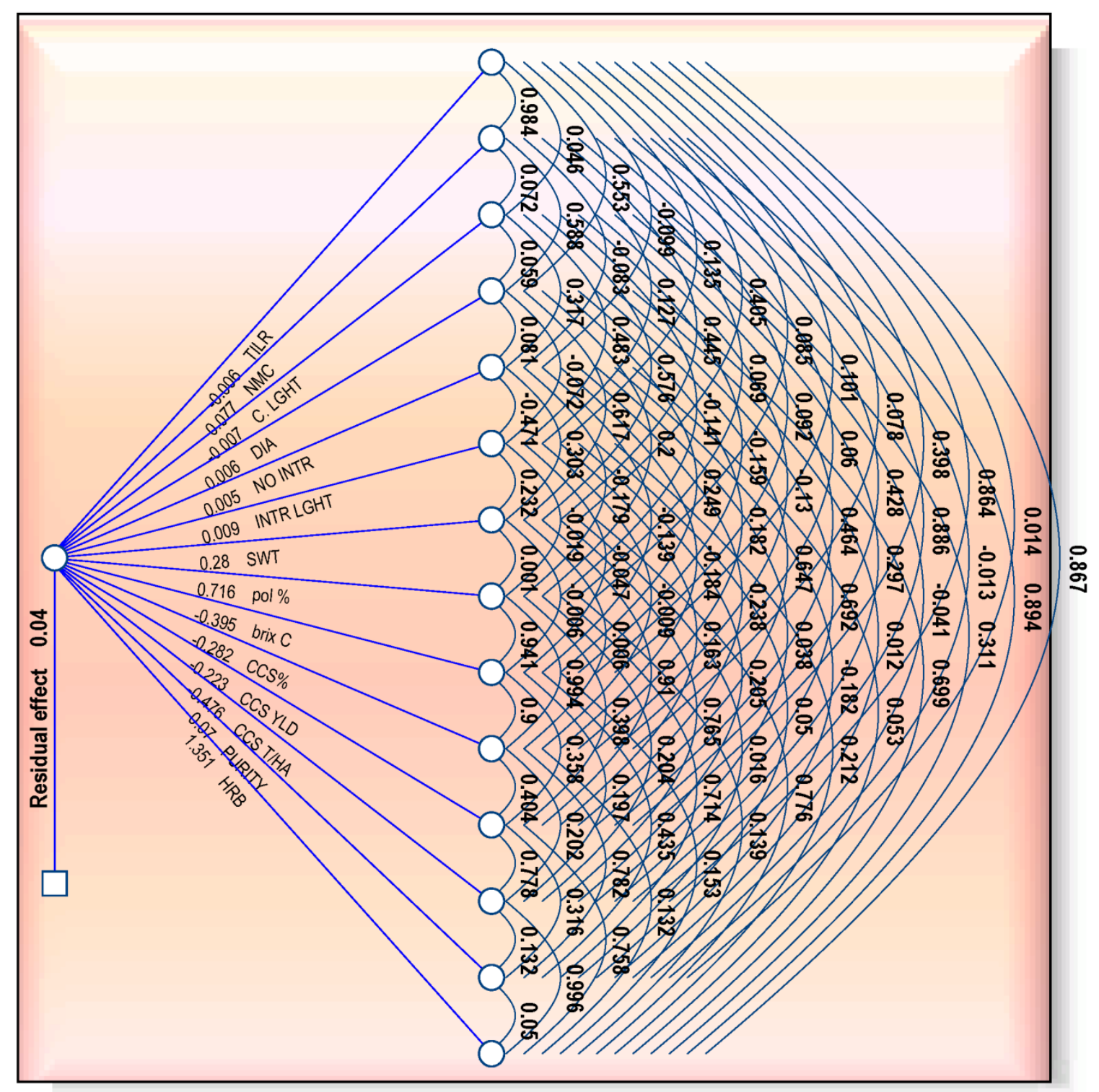

CCS yield also exhibited highest indirect effect on cane yield via all the cane attributing characters such as CCS yield (t/ha), single cane weight, number of millable canes, cane length, internode length, cane diameter and numbers of internodes except number of tillers which showed negative indirect effect on cane yield. Single cane weight showed positive indirect effect on cane yield via CCS yield (t/ha), single cane weight, cane length, internode length, cane diameter and numbers of internodes.

The results revealed that, among the cane characters studied, HR Brix yield (t/ha) had highest positive direct effect of 1.3507 on cane yield followed by pol per cent (0.7161), single cane weight $(0.2798)$ and number of millable canes (0.0774). Number of internodes, cane diameter and inter node 
length exhibited lowest positive direct effects of $0.0049,0.0056$, and 0.0086, respectively. While low direct contribution to cane yield by CCS yield (-0.2230), CCS yield (-0.4757) and number of tillers $(-0.0065)$ were found to be negative.

Critical analysis of the results by path analysis revealed that the characters HR Brix yield, single cane weight, pol per cent and number of millable canes observed high positive direct effects on cane yield and the other characters also exhibited their indirect positive effects on cane yield via these characters indicating that these are the major contributing characters to cane yield in sugarcane. Hence, direct selection for HR Brix yield, cane weight and NMC would be helpful for the improvement of cane yield in first clonal stage of sugar cane.

\section{References}

Anonymous, 2017, http//www. faostat. com Anonymous, 2017, http//www. indiastat. Com Charumathi, M. 2011, Studies on selection indices in sugarcane (Saccharum officinarum L.). Ph.D., Thesis submitted to the Acharya N. G. Ranga Agricultural University Hyderabad.

Guruprasad Hiremath, 2012, Morphological traits and DNA markers assay based diversity in selected clones of sugarcane. M.Sc. (Agri). Thesis, Univ. Agric. Sci., Bangalore, 197 pp.

Kang, M. S., Sosa, O. and Miller, J. D., 1989, Path analyses for per cent fibre and cane and sugar yield in sugarcane. Crop Sci., 29(6): 1481-1483.

Kasayya., 2016, Genetic investigation in midlate maturing sugarcane (Saccharum officinarum) clones isolated for Cauvery command area, M. Sc.(Agri). Thesis, Univ. Agric. Sci., Bangalore, 107 pp.

Ram, B., Sahi, B.K and Chaudhary, B.S. 2000, Effect of selection stages on relationships between attributes in sugarcane. Sugar Cane International. August: 5-11.

Shanthi Priya., 2013, Biometrical investigations on diversified uses in sugarcane (Saccharum spp.). M.Sc. (Agri). Thesis, Acharya N. G. Ranga Agri. Univ., pp. 525.

Suresh Jaganur., 2014, Evaluation of elite clones of sugarcane (Saccharum officinarum) for cane yield, quality traits and rationing ability. M. Sc.(Agri). Thesis, Univ. Agric. Sci., Bangalore, pp 85.

Thippeswamy, S., Kajjidoni, S. T., Salimath, P. M. and Goud, J. V., 2003, Correlation and Path analysis for cane yield, juice quality and their component traits in sugarcane. Sugar Technol., 5(1\&2): 65-72.

\section{How to cite this article:}

Somu, G., M.S.P. Kanavi, C. Shashikumar, Shivaray Navi and Meena, N. 2020. Path Coefficient Analysis in First Clonal Stage of Sugarcane (Saccharum officinarum L.). Int.J.Curr.Microbiol.App.Sci. 9(09): 2682-2689. doi: https://doi.org/10.20546/ijcmas.2020.909.334 